\title{
Pediatric Mixed-Phenotype Acute Leukemia: What's New?
}

\author{
Sandeep Batra * and Anthony John Ross
}

check for

updates

Citation: Batra, S.; Ross, A.J. Pediatric Mixed-Phenotype Acute Leukemia: What's New?. Cancers 2021, 13, 4658. https://doi.org/ $10.3390 /$ cancers 13184658

Academic Editor: Csongor Kiss

Received: 16 August 2021

Accepted: 12 September 2021

Published: 16 September 2021

Publisher's Note: MDPI stays neutral with regard to jurisdictional claims in published maps and institutional affiliations.

Copyright: (c) 2021 by the authors. Licensee MDPI, Basel, Switzerland. This article is an open access article distributed under the terms and conditions of the Creative Commons Attribution (CC BY) license (https:// creativecommons.org/licenses/by/ $4.0 /)$.

\author{
Department of Pediatrics, Indiana University School of Medicine, Riley Hospital for Children at Indiana \\ University Health, Indianapolis, IN 46202, USA; rossant@iu.edu \\ * Correspondence: batras@iu.edu
}

Simple Summary: Pediatric mixed-phenotype leukemia is a rare form of blood cancer in children. In this review, we cover both the evolution of treatment over the past several years and outline new emerging concepts in this disease.

\begin{abstract}
Mixed-phenotype acute leukemias (MPAL) are rare in children and often lack consensus on optimal management. This review examines the current controversies and emerging paradigms in the management of pediatric MPAL. We examine risk stratification, outcomes of recent retrospective and prospective collaborative trials, and the role of transplantation and precision genomics, and outline emerging targets and concepts in this rare entity.
\end{abstract}

Keywords: mixed-phenotype acute leukemia; MPAL; Ph+; MLL; lineage switch; minimal residual disease; treatment

\section{Introduction}

Mixed phenotypic acute leukemias (MPAL) are rare hematological malignancies in children, accounting for less than $5 \%$ of pediatric acute leukemias [1-4]. MPAL are heterogeneous and can exhibit cross-lineage myeloid, B-lymphoid, or T-lymphoid antigen expression on a single blast population (biphenotypic) or have distinct single-lineage blast populations (bilineal) [3]. Due to phenotypic and genetic diversity, lack of welldefined diagnostic criteria, treatment resistance, and lineage switch, MPAL often present a diagnostic dilemma, and prove difficult to treat.

Biphenotypic MPAL are more common than bilineal MPAL. However, the true prevalence and survival can be difficult to determine given the various diagnostic criteria utilized, lack of a centralized review of cases, and treatment protocols that are based on results from retrospective studies. The Children's Oncology Group Acute Leukemia of Ambiguous Lineage Task Force reported that routine institutional flow cytometry was insufficient for the diagnosis of MPAL in about $15 \%$ of children, which further highlights the diagnostic challenge faced by oncologists [5].

\section{Classification of MPAL}

Currently, MPAL are classified based on lineage-specific immunophenotypic markers determined by flow cytometry, immunohistochemistry, or cytochemistry and primary molecular alteration, and are considered by most co-operative groups to be highrisk leukemias [5]. The majority of MPAL present as B-lymphoid/myeloid (in about $2 / 3$ cases), with a T-lymphoid/myeloid immunophenotype being the second most common presentation. Rarely, it can present as B-lymphoid/T-lymphoid or B-lymphoid/Tlymphoid/myeloid subtypes [6-8]. Myeloid-surface antigen co-expression does not appear to be prognostic [3]. The classification of MPAL also includes two distinct entities: MPAL with KMT2A (mixed-lineage leukemia or MLL) rearrangement and MPAL with $\mathrm{t}(9 ; 22)(\mathrm{q} 34.1 ; \mathrm{q} 11.2) ; B C R-A B L 1$ (Philadelphia chromosome positive or $\mathrm{Ph}+$ ).

After MPAL were recognized as a distinct entity, numerous sets of diagnostic criteria were established, including the European Group for the Immunological Characterization of 
Leukemias (EGIL), and most recently the World Health Organization (WHO) 2016 system (updated from previous WHO 2008 classification), which is being increasingly utilized for MPAL diagnosis $[6,9,10]$. A hallmark of MPAL in the WHO classification scheme rests on the fact that other leukemia subtypes (i.e., AML-defining balanced translocations such as $t(8 ; 21)$ that frequently expresses multiple B-cell markers) must be excluded prior to the MPAL designation [11]. Given its more widespread adaption in clinical practice, the World Health organization (WHO) 2016 criteria are presented in Tables 1 and 2. There are distinct differences between the classification schema, with the European Group for the Immunological Classification of Leukemias (EGIL) scheme generally considered to be more inclusive, which often leads to more acute leukemias being classified as MPAL, and a higher incidence of MPAL compared to the WHO classification. Weinberg et al. published a review looking at 7627 patients (both pediatrics and adults) with leukemia showing a mixed phenotype incidence of $2.8 \%$ using EGIL compared with $1.6 \%$ when using WHO 2008 criteria [3,11].

Table 1. Criteria for lineage assignment in mixed phenotypic acute leukemia.

\begin{tabular}{c} 
Lineage Assignment Criteria \\
Myeloid Lineage \\
\hline MPO+ (Flow cytometry, immunohistochemistry, or cytochemistry) \\
or \\
Monocytic differentiation (at least two of the following: nonspecific esterase cytochemistry, \\
CD11c, CD14, CD64, lysozyme) \\
T-Lymphoid Lineage \\
\hline Strong * cytoplasmic CD3 (with antibodies to CD3 $\varepsilon$ chain) \\
or \\
Surface CD3 \\
\hline B-Lymphoid Lineage \\
CD22, or CD10 \\
or \\
Weak CD19 with at least 2 of the following strongly expressed: CD79a, cytoplasmic \\
CD22, or CD10
\end{tabular}

Table 2. WHO 2016 criteria for acute leukemia of ambiguous lineage.

\begin{tabular}{c}
\hline Acute Undifferentiated Leukemia \\
\hline Mixed-phenotype acute leukemia (MPAL) with $\mathrm{t}(9 ; 22)(\mathrm{q} 34.1 ; \mathrm{q} 11.2) ; \mathrm{BCR}-\mathrm{ABL} 1$ \\
\hline MPAL with $\mathrm{t}(\mathrm{v} ; 11 \mathrm{q} 23.3) ; \mathrm{KMT} 2 \mathrm{~A}$ rearranged \\
\hline $\mathrm{MPAL}, \mathrm{B} /$ myeloid, NOS \\
$\mathrm{MPAL}, \mathrm{T} /$ myeloid, NOS
\end{tabular}

Further classification of MPAL can be implemented utilizing the mutational status of the leukemia. Most MPAL have an abnormal and often complex karyotype, with $\mathrm{t}(9 ; 22)$ mostly identified in adult or older patients, whereas $\mathrm{t}(\mathrm{v} ; 11 \mathrm{q} 23)$ ( $A F F 1$ is the most common fusion partner of $M L L$ ) is primarily seen in infant B/myeloid MPAL [11]. Matutes et al. looked at 100 MPAL patients diagnosed using the WHO 2008 criteria and found that the most common abnormality was a complex karyotype in $32 \%$ of patients, $t(9 ; 22)$ in $20 \%$, and normal karyotype in only 13\% [8]. Less commonly, chromosome 1, 6, and 12 deletions; trisomy 4 ; and near-tetraploidy have been reported $[5,6,8]$. These mutations aid in subclassification but the therapeutic and prognostic importance is still under appreciated. 


\section{Molecular Studies in MPAL}

The development of MPAL is thought to occur either through the progression of sequential mutations that drive a leukemia cell towards a multi-lineage phenotype or arise from primitive hematopoietic cells with multipotency that develop clonal evolution [12,13]. Evidence presented by Alexander et al. supports the primitive cell mechanism by displaying similar founder mutations and genomic imprinting throughout multiple subclones in MPAL patient samples [12].

A recent study out of St. Jude Children's Research Hospital analyzed the largest cohort of over one hundred cases of pediatric MPAL which identified genomic patterns that showed several recurrent alterations common in ALL (i.e., ETV6), AML (i.e., FLT3 and RUNX1), as well as those seen in both ALL/AML (i.e., WT1 and KMT2A) [12]. Of note, there were unique mutational patterns noted between $\mathrm{B} /$ myeloid and $\mathrm{T} /$ myeloid MPAL. These mutations include alterations in the JAK-STAT pathway in T/myeloid MPAL (seen in $57 \%$ versus $23 \%$ of B/myeloid) and ZNF384 rearrangements in B/myeloid, which leads to a higher FLT3 expression than typical B-ALL or T-lymphoid/myeloid MPAL [12].

Recent publications have utilized comprehensive next-generation sequencing (NGS) to reveal the complex genetic landscape of MPAL which may further impact diagnosis, treatment strategies, and prognosis. The majority of $\mathrm{B} /$ Myeloid MPAL harbor RAS and epigenetic regulator mutations, with NRAS and PTPN11 and MLLT3, KMD6A, EP300, and CREBBP being commonly altered [12]. Compared with T-ALL patients, $\mathrm{T} /$ myeloid MPAL demonstrate a lower frequency of alterations in $C D K N 2 A / B, N O T C H 1$, and core transcription factors [12]. Most studies investigating the mutational landscape of T/Myeloid MPAL are limited by small numbers but have reported mutations in ETV6, NOTCH1, WT-1, and FLT3, as well as in epigenetic modifiers or regulators, IKZF1 (Ikaros), and JAK/STAT signaling proteins [12,14-17]. Additionally, a retrospective trial out of Memorial Sloan Kettering showed that MPAL with a T-lymphoid component had higher expression of mutations in PHF6 (seen in younger patients) and DNMT3A (seen in older patients), which is line with previous work $[7,18]$.

Additional studies with a limited number of patients have been conducted in adult patients, further elucidating the diverse genetic landscape of MPAL. A study conducted by Takahashi et al. looked at thirty-one adult MPAL patients and saw unique mutational patterns between MPAL subtypes (particularly B-lymphoid/myeloid and T-lymphoid/myeloid) [19]. Of note, the commonly seen rearrangement in ZNF384 seen in the St. Jude pediatric population of B-myeloid MPAL was not seen in the adult cohort and would limit FLT3 as a target of therapy $[7,19]$.

In summary, the studies outlined above elucidate the heterogenous biology and lineage plasticity of MPAL, and future work may help identify unique targetable molecular lesions, using precision genomics, in patients with poor response to therapy.

\section{Lineage Switch in MPAL}

Lineage switch is a phenomenon in which a lymphoid leukemia converts to a myeloid leukemia (more common), but the opposite switch has also been reported [20]. This phenomenon is of particular interest in MPAL, is more commonly reported in KM2TA (MLL)-rearranged leukemias, and often complicates management of these patients [21].

A review article by $\mathrm{Hu}$ et al. has elegantly outlined that the mechanisms of lineage switch are not fully understood and presents several complimentary hypotheses [20]. One hypothesis is that leukemic clones involved in lineage switches and ambiguous leukemias may in fact be derived from multipotent hematopoietic cells $[20,22]$. This concept is further supported by methylation studies performed by Alexander et al. [12]. Another potential mechanism of lineage switch involves leukemic cell reprogramming by transcription factors. It is well known that transcription factors are important for normal hematopoiesis and loss of transcriptional regulation can lead to leukemia development [20,23]. Overexpression of Pu.1 (an important transcription factor for myeloid regulation) has been shown to cause lineage switch in mouse models, as well as in a case of myeloid switch adult 
leukemia [20,24,25]. Pax 5 is considered an important transcription factor for B-lymphoid lineage differentiation with high levels seen in B-ALL and lower levels seen in MPAL following a lineage switch (i.e., after CD19-directed CAR-T cell therapy) $[20,26]$. The pressure from the cytokine microenvironment may also play a pivotal role in lineage ambiguity/switch. B-ALL cells have been reprogrammed into myeloid cells (non-leukemic macrophages) through exposure to pro-myeloid cytokines including IL-3 and GM-CSF in in vitro models, which suggests microenvironmental pressure may impact leukemia lineage [27]. The importance of transcription factor and tumor microenvironmental changes is not specific to MPAL but the importance has also been seen in mature B-cell lymphomas (including the importance of IL-6 and PAX5) [28,29]. A simplified diagram highlighting the impact of transcription factors and cytokines is shown in Figure 1.

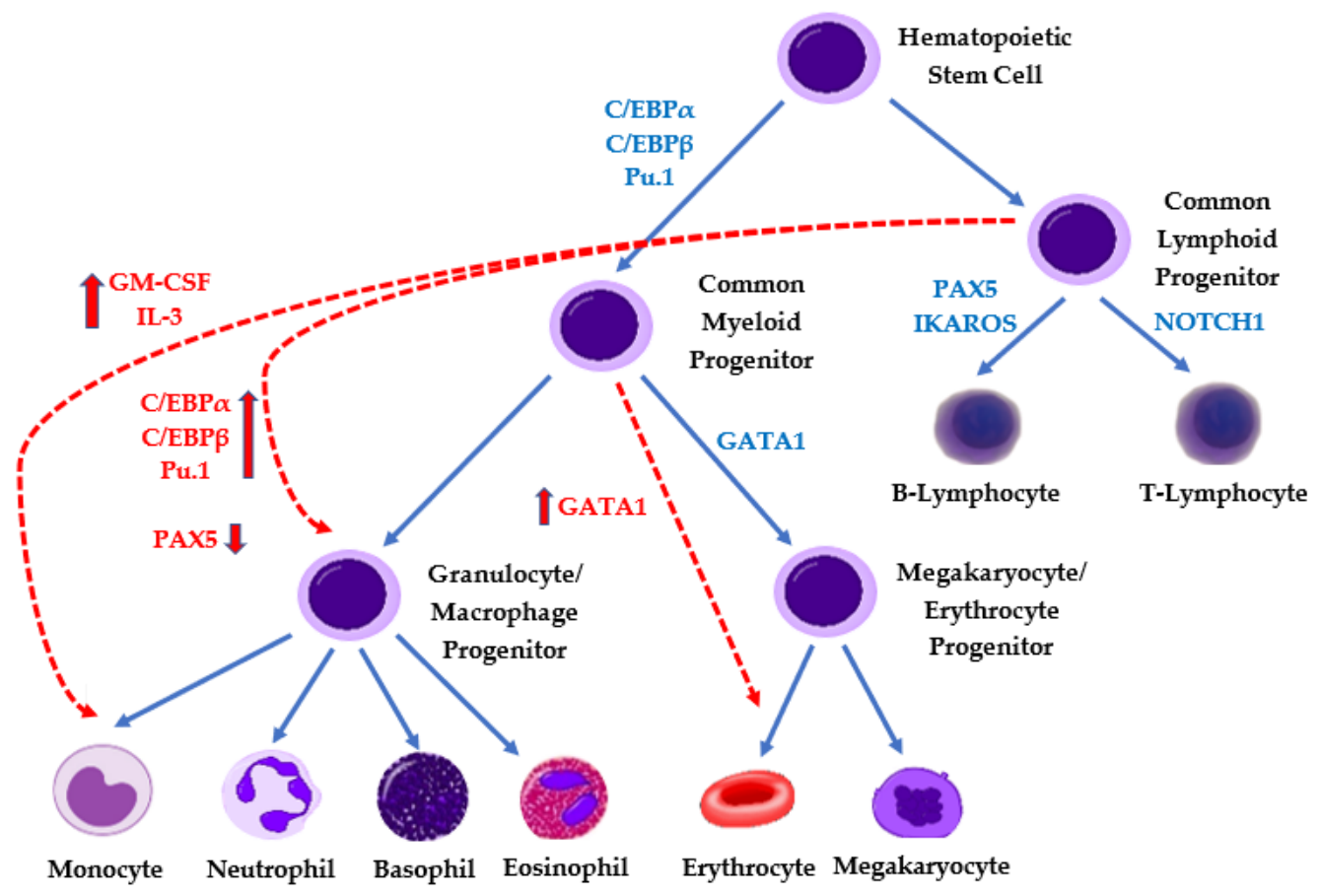

Figure 1. Regulation of lineage commitment in hematopoiesis. Solid lines/blue text indicate regulators of normal hematopoiesis, and red lines (-) and text highlight aberrant regulation implicated in MPAL pathogenesis.

Finally, treatment-related clonal selection pressure may lead to lineage switch or development of a mixed-lineage leukemia. This is of particular interest with the increased use of B-ALL-directed immunotherapy, which has been linked to lineage switch, particularly in KMT2A-rearranged leukemias [20,21,26,30,31]. It is unclear if selective killing of a CD19-positive clone with subsequent expansion of a more myeloid clone is to blame or if transcriptional alteration (upregulation of $P u .1$ and downregulation of Pax5) could play a role [26]. A simplified schema outlining potential mechanisms of lineage switch in acute MPAL is presented in Figure 2. 


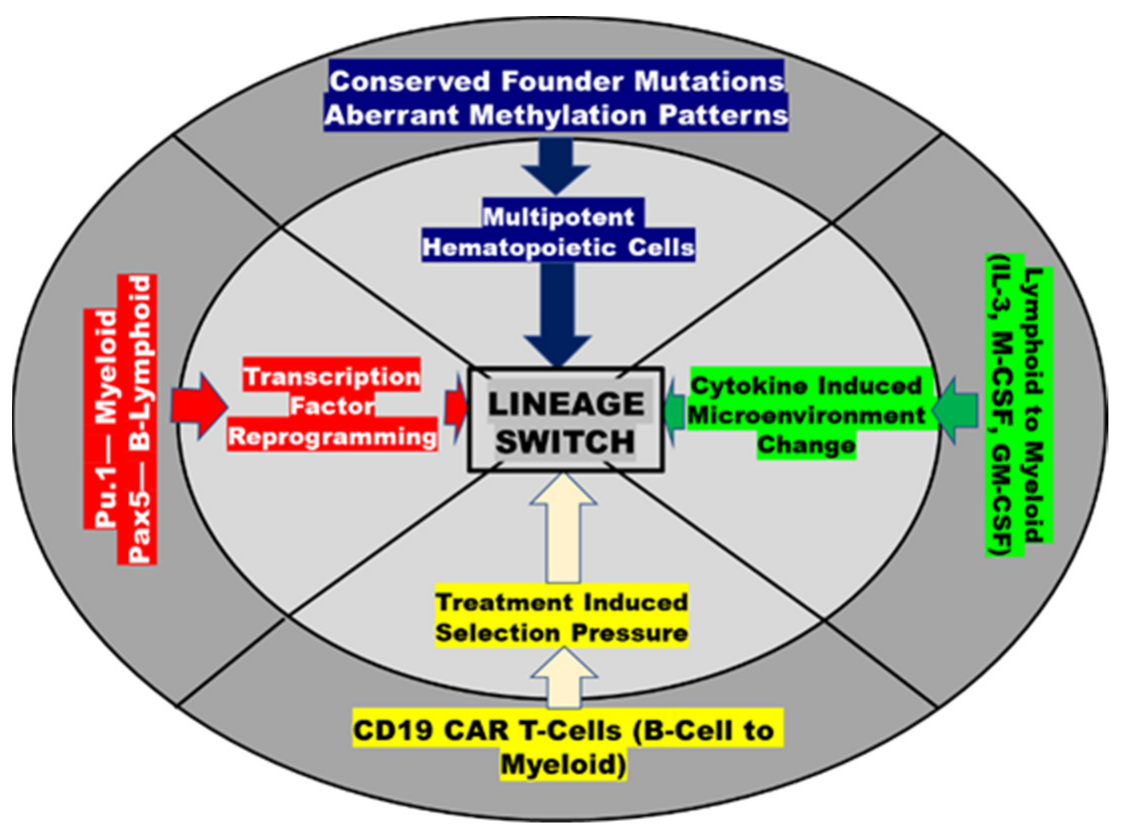

Figure 2. Potential mechanisms causing lineage switch in MPAL.

\section{Treatment of MPAL}

Historically, MPAL have inferior outcomes and a high risk of induction failure, compared with ALL/AML, and are treated per high-risk leukemias protocols [32]. Poor prognostic factors include: an older age at diagnosis, higher white blood cell (WBC) count at presentation, T-lymphoid/myeloid phenotype, adverse cytogenetics (such as a KMT2A/AFF1 rearrangement), extramedullary disease at diagnosis, and MRD positivity $[11,33,34]$. There have been various chemotherapy approaches for the treatment of MPAL including acute ALL, AML, and hybrid ALL/AML (such as FLAG (fludrabine, cytarabine, granulocyte-stimulating factor)-IDA (idarubicin) with vincristine and prednisone (VCR-PRED) or hyper-CVAD (cyclophosphamide, vincristine, doxorubicin, and dexamethasone) regimens) $[8,35,36]$. Optimal therapy remains a subject of controversy and differences between adult and pediatric treatment approaches are often striking [8,37].

St. Jude Children's Research Hospital reviewed outcomes of 35 pediatric MPAL patients (treated from 1985 to 2006) and reported that the majority (65\%) of the patients received AML induction chemotherapy with cytarabine, daunomycin, and etoposide, while $35 \%$ of the patients received ALL four-drug induction [15]. In this review, of the patients treated with upfront AML therapy, 12/23 (52\%) achieved complete remission compared with $10 / 12(83 \%)$ with ALL therapy. Interestingly, $8 / 10(80 \%)$ of patients who did not achieve complete remission (CR) with AML therapy went into remission after being switched to ALL-like induction therapy [15]. Long-term survival was achieved in 17 out of 35 patients ( 5 patients treated with AML therapy and 12 patients treated with ALL therapy either upfront or after initial AML failure). The same study compared historical survival rates, comparing MPAL with standard ALL therapy to AML therapy. The 5-year survival estimates for MPAL (combined B/myeloid and T/myeloid) were $47.8 \% \pm 11.5 \%$, similar to that of AML $(56.5 \% \pm 3.5 \%)$, but were significantly less than patients receiving ALL therapy at $84.6 \% \pm 1.1 \%$ [15].

Previous studies on adults have shown that the historical 4-year survival for adult MPAL is less than 10\% [8]. A case series of 100 MPAL patients by Matutes et al. further showed that older patients had inferior survival compared with patients less than 15 years of age $[8,38]$. In this case, series median survival in adults was 11.8 months compared with 139 months in children. A similar pattern was seen in patients treated with ALL therapy, 
with a median survival of 139 months compared with 11 months with AML therapy and 3 months with a hybrid approach [8].

However, more recently, due to improved diagnostic criteria and genomic techniques, and the observation that ALL-like regimens in both pediatric and adult populations are associated with superior treatment response, the treatment landscape has clearly changed [5,35,39-41].

Several other studies have also investigated optimal upfront therapy for patients with MPAL, and support that notion that ALL treatment regimens tend to lead to better overall survival than AML-based regimens $[1,7,11,16,38,39,42-44]$. The BFM group international pediatric cooperative study (AMBL2012) demonstrated a superior outcome when patients were treated with ALL primary therapy with a 5-year event-free survival (EFS) of $80 \% \pm 4 \%$ compared with AML therapy $(36 \% \pm 7.2 \%)$ or hybrid ALL/AML therapy $(50 \% \pm 12 \%)$ [36]. In particular, ALL/AML hybrid approach in KMT2A-rearranged patients resulted in a subpar 5-year EFS of only 28\% [36]. A 2018 systematic review from Maruffi et al. looked at over 1300 adults and children diagnosed with MPAL and showed that ALL induction regimen was more likely to lead to remission $(\mathrm{OR}=0.33)$ and improved overall survival $(\mathrm{OR}=0.45)$ compared to AML-like treatment protocols, or an even worse outcome associated with hybrid regimens [1]. Additionally, a recent multi-center analysis showed that ALL induction therapy was able to achieve MRD negative remission by the end of induction in a majority of patients (70\%) [40]. Even in studies showing similar survival benefits between ALL and AML/hybrid regimens, ALL regimens tend to lead to overall decreased morbidity, due to less toxicity, compared with AML or hybrid-based treatments [35]. Lumbar puncture is recommended at diagnosis to determine central nervous system (CNS) status for all MPAL patients, as frequency of CNS involvement is higher $[7,45]$. CNS-directed intrathecal chemotherapy is administered, similar to treatment protocols for acute leukemia with CNS involvement.

A recent review from Children's Healthcare of Atlanta, highlights that patients with $\mathrm{B}$ /myeloid MPAL with isolated MPO expression might in fact be a unique entity, and have a more favorable response to ALL therapy [46]. In this review, patients with B/myeloid with isolated MPO had an overall survival rate at 3 years of $100 \%$ compared with $63.1 \%$ with other MPAL, and interestingly, the degree of MPO positivity was not prognostically relevant [46]. This highlights that the detection of a B/MPAL phenotype with isolated MPO expression is important, and may allow for better prognostic information and treatment decisions.

MPAL with KMT2A (MLL) rearrangement, are more common in children than adults, are typically bilineal (lymphoblasts and monoblasts) but rarely biphenotypic, and are prone to lineage switch $[21,24,30,37]$. The fusion partner of MLL1 is a determinant of the leukemic phenotype [47]. For example, MLL-AF4 is predominantly associated with a lymphoid phenotype and MLL-AF9 with a myeloid phenotype [47]; however, the role of fusion partners in determining MPAL phenotype or lineage switch remains unclear [48]. Compared with $P h+$ MPAL, the MLL+ MPAL patients have significantly inferior survival odds (HR $=10.2, p<0.001)[49]$, and are transplanted, upfront, if induction failure occurs, or at relapse $[11,50,51]$. New emerging targets blocking the $M L L$ fusion complex are under evaluation, include menin [52], disruptor of telomeric silencing 1-like (DOTL1) inhibitors [53], and spleen tyrosine kinase (SYK) inhibitors [54].

\section{Treatment of $P h+M P A L$}

$P h+$ acute ALL, with $\mathrm{t}(9 ; 22)(\mathrm{q} 34: \mathrm{q} 11.2)$, constitute $25 \%$ of MPAL, and are more common in adults than children, and often present with a B/myeloid phenotype and a p190 BCR$A B L$ transcript and have a high incidence of CNS involvement $[3,8,11]$. With the advent of successful TKI therapy directed against $B C R-A B L$, the treatment paradigm has shifted, and outcomes have improved significantly [49]. An ALL-chemotherapy backbone combined with a TKI is increasingly utilized, with comparable outcomes to Ph+ non-MPAL ALL [49]. However, Ph+ MPAL must be distinguished from CML with mixed blast crisis, as the 
latter is treated with AML-like therapy followed by allogeneic transplant. CML is usually associated with a $p 210$ isoform, and MPAL usually express the $p 190$, although each could be associated with either isoform. Prior history of a chronic phase or accelerated phase may also distinguish these entities $[55,56]$.

\section{Role of Hematopoietic Stem Cell Transplantation}

The role of hematopoietic stem cell transplantation (HSCT) in MPAL remains controversial and recommendations may vary based on the age of the patient being considered. Several adult retrospective trials show that survival is poor with chemotherapy alone and that there is possible benefit for the use of HSCT if a patient is able to obtain complete remission (CR) $[1,50,51,57,58]$. Munker et al. analyzed a large adult cohort for HSCT outcomes in MPAL: the 3-year overall survival was $56 \%$, which is an improvement over the historical SEER data for patients older than 20 years of age, which tend to be 20-40\% [59]. On the other hand, several studies have shown there is no clear benefit for the use of HSCT in pediatric MPAL, and that most pediatric MPAL are able to be treated with ALL-based chemotherapy regimens alone $[17,58,59]$. In pediatrics, HSCT is typically only pursued in patients with induction failure, a high minimal residual disease (MRD) $>5 \%$ at end of induction (EOI) or persistent MRD positivity at the end of consolidation (EOC), or after lineage switch [5]. There is a survival advantage if total body irradiation is incorporated into the transplant conditioning (similar to ALL), when compared with other preparative regimens [57].

Relapsed MPAL post transplantation remains a major challenge, and generally there is no consensus for further management of these cases. Patients treated with an ALL approach appear to be less likely to relapse than patients treated with an AML therapy approach. In addition, the remission durations of relapsed patients tend to be shorter, while age, lineage switch, and higher white counts are not predictive of worse outcomes per se [60].

\section{Assessing Response/Impact of MRD}

MRD by flow cytometry or next-generation sequencing (NGS) is a well-established technique to assess therapy response and prognosis in acute leukemias [32,61]. MRD positive disease following intense chemotherapy has been shown to be a powerful prognostic indicator in pediatric and adult B-ALL [62]. MRD evaluation in MPAL presents unique challenges, due to variable antigen expression, potential for lineage switch, the lack of validated MRD assays assessing the dual expression or bilineal blasts, and the lack of established thresholds to assess for adequate therapy response [7].

Despite these challenges, MRD positivity has been linked to worse outcomes in MPAL. Patients with EOI MRD $\geq 5 \%$ performed poorly in the iBFM AMBL2012 trial with a 5-year EFS of less than 50\% [36]. Furthermore, this trial demonstrated that patients who achieved an MRD $<0.01 \%$ by the EOC had excellent outcomes with an overall survival of near $90 \%[5,36]$. An additional multi-center review of almost 100 pediatric MPAL patients showed that MRD positivity at EOI was associated with worse EFS and OS (HR $=6.00$ and $\mathrm{HR}=9.57$ respectively) [40]. This flow-cytometry-based MRD-directed approach has been incorporated by the Children's Oncology Group (COG) to identify MPAL treatment failures [5]. NGS-based MRD assays or identification of mutational hotspots may assist in tracking and assessing one or more populations of MPAL blasts and requires further study [5]. A high end of induction or consolidation MRD may necessitate augmentation of therapy, a switch from ALL to AML directed therapy, and a consolidative hematopoietic stem cell transplant [1].

\section{Novel Approaches}

With the growing molecular/genetic understanding of MPAL, this opens the door for potential targeted, novel therapeutic approaches. These targeted therapies include those already being successfully utilized in the treatment of B-ALL, including tyrosine kinase 
inhibitors for Ph+/Ph-like disease [63-65] and FLT3 inhibitors used in MLL-rearranged disease $[12,66]$. $B C R-A B L$ translocations had previously been shown to have poor outcomes in MPAL, but with the addition of TKI therapy to an ALL backbone they have outcomes similar to Ph+ B-ALL [65]. FLT3 inhibition is an attractive option, particularly given the data from St. Jude showing the increased prevalence of ZNF384 rearrangement leading to upregulated FLT3 expression in B-lymphoid/myeloid MPAL. Pre-clinical and clinical research has been conducted in KMT2A-rearranged leukemia (particularly in infants) and has shown increased sensitivity to both FLT3 and RAS inhibition, which could be translated into MPAL patients harboring such mutations [67-69]. Novel agents such as $B C L-2$ inhibitor venetoclax, in combination with hypomethylating agents, have been used to induce remission in MPAL [70-72]. Given the unique biology of MPAL, engineering hematopoietic stem cells harboring altered transcription factor profiles could mimic a pre-clinical model and allow the expanded testing of novel target agents, using a precisionmedicine approach.

An expanding area of research includes the use of immunotherapy for the treatment of hematologic malignancies. Immunotherapies, including bispecific T-cell engagers (BITE) and chimeric antigen receptor T-cells (CART), have been successfully utilized for the treatment of CD19+ relapsed/refractory B-ALL [73-76]. There is growing evidence that these therapies can also be utilized in the treatment of MPAL. Recent case reports and small retrospective reviews support the use of CD19 BITE cells and CART cells as efficacious treatments for refractory MPAL [77-80]. A recent case series from Bartram et al. out of the United Kingdom presented three pediatric cases of refractory MPAL that successfully utilized Blinatumomab as a bridge to transplant, including in a patient with a significant CD19-negative blast component [81]. Given the presence of different lineage antigens in MPAL, it is thought that bi-specific immunotherapy options might be more efficacious. Pre-clinical data have shown that dual-targeting triplebody therapy directed against CD33/CD3/CD19 leads to selective and effective lysis of biphenotypic B/myeloid cells expressing CD19 and CD33 [82,83]. A recent case report successfully utilized two immunotherapy options targeting separate antigens (Blinatumomab for CD19 and Gemtuzumab for CD33) to successfully treat a refractory, KMT2A-rearranged infant MPAL [37]. Table 3 summarizes clinical reports that highlight the successful use of immunotherapy in MPAL. Despite potential success, the use of direct/immunotherapy-based treatment strategies for MPAL proposes unique challenges, including selective pressure towards treatment resistance and lineage switch, requiring further studies.

Table 3. Clinical reports utilizing immunotherapy to treat MPAL (FLA: fludrabine, cytarabine; IDA: idarubicin).

\begin{tabular}{|c|c|c|c|}
\hline Reference & MPAL Patients & Treatments & Outcomes \\
\hline Bartram et al. [81] & $\begin{array}{c}\text { Patient 1: } \\
\text { 6-month-old female with B/Myeloid } \\
\text { MPAL with KMT2A deletion } \\
\text { Patient 2: 10-month-old male with } \\
\text { B/Myeloid, KMT2A-USP2, and FLT3 } \\
\text { ITD } \\
\text { Patient 3: 72-month-old female with } \\
\text { B/Myeloid MPAL and } \\
\text { KMT2A-ARHGEF12 }\end{array}$ & $\begin{array}{l}\text { ALL induction followed by FLA-IDA } \\
\text { (myeloid regimen) with CD19+ MRD, } \\
\text { and Blinatumomab followed by HSCT } \\
>10 \% \text { disease after ALL induction } \\
\text { (CD19+, CD19-, populations): } \\
\text { Blinatumomab and FLA-IDA prior to } \\
\text { HSCT } \\
\text { ALL induction followed by } \\
\text { Blinatumomab and high-dose Ara-C } \\
\text { prior to HSCT }\end{array}$ & $\begin{array}{l}\text { CR for } 24 \text { months post HSCT } \\
\text { CR for } 8 \text { months post HSCT } \\
\text { CR } 5 \text { months post HSCT }\end{array}$ \\
\hline Li et al. [77] & $\begin{array}{l}\text { 29-year-old male with B/myeloid } \\
\text { CD19+ MPAL and SET-NUP14 fusion } \\
\text { gene transcript }\end{array}$ & $\begin{array}{l}\text { ALL induction followed by hybrid } \\
\text { Consolidation (hyper-CVAD-B and } \\
\text { hyper-CVAD-A) and HSCT } \\
\text { For Relapse\#1: received CD19 } \\
\text { Directed CART therapy x2 } \\
\text { (donor-derived) }\end{array}$ & $\begin{array}{l}\text { Relapse\#1 after } 6 \text { months } \\
\text { Relapse\#2: } 24 \text { months following } \\
\text { first infusion of CAR T-Cells } \\
\text { despite persistent CD19 CAR } \\
\text { T-Cells at } 8 \text { months }\end{array}$ \\
\hline Durer et al. [77] & $\begin{array}{l}\text { 51-year-old female with B/myeloid } \\
\text { CD19+ MPAL }\end{array}$ & $\begin{array}{l}\text { ALL induction followed by HSCT but } \\
\text { relapsed after } 3 \text { months. Received } \\
\text { Blinatumomab and donor lymphocyte } \\
\text { infusions (x } 4 \text { cycles) }\end{array}$ & $\begin{array}{l}\text { Attained CR after one cycle and } \\
\text { maintained CR for } 15 \text { months }\end{array}$ \\
\hline
\end{tabular}


Table 3. Cont

\begin{tabular}{|c|c|c|c|}
\hline Reference & MPAL Patients & Treatments & Outcomes \\
\hline El Chaer et al. [78] & $\begin{array}{c}\text { Patient 1: 39-year-old male with Ph+ } \\
\text { B/myeloid MPAL } \\
\text { Patient 2: 55-year-old female with } \\
\text { B/myeloid }\end{array}$ & $\begin{array}{c}\text { Induction with Cytarabine, } \\
\text { Daunorubicin, and Dasatinib followed } \\
\text { by Blinatumomab with HSCT } \\
\text { HyperCVAD (held due to toxicity), } \\
\text { and later received } 3 \text { cycles of } \\
\text { Blinatumomab followed by HSCT }\end{array}$ & $\begin{array}{l}\mathrm{CR} \text { at } 6 \text { months } \\
\mathrm{CR} \text { at } 14 \text { months }\end{array}$ \\
\hline Brethon et al. [37] & $\begin{array}{l}\text { 4-month-old female with B/myeloid } \\
\text { MPAL with KMT2A-AFF1 }\end{array}$ & $\begin{array}{l}\text { Interfant-06 protocol with refractory } \\
\text { disease; received Blinatumomab and } \\
\text { Gemtuzumab followed by HSCT, } \\
\text { followed by CART for relapse }\end{array}$ & $\begin{array}{l}\text { Relapsed } 11 \text { months post HSCT; } \\
\text { then achieved CR for } 12 \text { months } \\
\text { post CART }\end{array}$ \\
\hline
\end{tabular}

\section{Conclusions and Future Directions}

MPAL are a heterogeneous group of leukemias that often have a complex phenotype/genetic basis and historically have been difficult to diagnose and treat. Despite recent advances in the diagnosis criteria and treatment landscape of MPAL, there is still much to learn about this unique subset of acute leukemias. As most current treatment recommendations are based on retrospective studies, prospective clinical trials standardizing the treatment regimens and utilizing MRD for assessing treatment response, such as the ongoing COG trial AALL1732, are urgently needed to solidify a uniform approach for the management of MPAL.

Author Contributions: Conceptualization, S.B.; methodology, S.B. and A.J.R.; software, S.B. and A.J.R.; validation, S.B. and A.J.R.; formal analysis, S.B. and A.J.R.; investigation, S.B. and A.J.R.; resources, S.B. and A.J.R.; data curation, S.B. and A.J.R.; writing-original draft preparation, S.B. and A.J.R.; writing—review and editing, S.B. and A.J.R.; visualization, S.B. and A.J.R.; supervision, S.B.; project administration, S.B. and A.J.R.; funding acquisition, S.B. Both authors have read and agreed to the published version of the manuscript.

Funding: This research received no external funding.

Conflicts of Interest: The authors declare no conflict of interest.

\section{References}

1. Maruffi, M.; Sposto, R.; Oberley, M.J.; Kysh, L.; Orgel, E. Therapy for children and adults with mixed phenotype acute leukemia: A systematic review and meta-analysis. Leukemia 2018, 32, 1515-1528. [CrossRef]

2. Weir, E.G.; Ansari-Lari, M.A.; Batista, D.A.S.; Griffin, C.A.; Fuller, S.; Smith, B.D.; Borowitz, M.J. Acute bilineal leukemia: A rare disease with poor outcome. Leukemia 2007, 21, 2264-2270. [CrossRef] [PubMed]

3. Weinberg, O.K.; Arber, D.A. Mixed-phenotype acute leukemia: Historical overview and a new definition. Leukemia 2010, 24, 1844-1851. [CrossRef]

4. Steensma, D.P. Oddballs: Acute Leukemias of Mixed Phenotype and Ambiguous Origin. Hematol. Oncol. Clin. 2011, 25, 1235-1253. [CrossRef] [PubMed]

5. Orgel, E.; Alexander, T.B.; Wood, B.L.; Kahwash, S.; Devidas, M.; Dai, Y.; Alonzo, T.A.; Mullighan, C.G.; Inaba, H.; Hunger, S.P.; et al. Mixed-phenotype acute leukemia: A cohort and consensus research strategy from the Children's Oncology Group Acute Leukemia of Ambiguous Lineage Task Force. Cancer 2020, 126, 593-601. [CrossRef]

6. Arber, D.A.; Orazi, A.; Hasserjian, R.; Thiele, J.; Borowitz, M.J.; Le Beau, M.M.; Bloomfield, C.D.; Cazzola, M.; Vardiman, J.W. The 2016 revision to the World Health Organization classification of myeloid neoplasms and acute leukemia. Blood 2016, 127, 2391-2405. [CrossRef] [PubMed]

7. Wolach, O.; Stone, R.M. Optimal therapeutic strategies for mixed phenotype acute leukemia. Curr. Opin. Hematol. 2020, 27, 95-102. [CrossRef]

8. Matutes, E.; Pickl, W.F.; Van't Veer, M.V.; Morilla, R.; Swansbury, J.; Strobl, H.; Attarbaschi, A.; Hopfinger, G.; Ashley, S.; Bene, M.C.; et al. Mixed-phenotype acute leukemia: Clinical and laboratory features and outcome in 100 patients defined according to the WHO 2008 classification. Blood 2011, 117, 3163-3171. [CrossRef]

9. Catovsky, D.; Matutes, E.; Buccheri, V.; Shetty, V.; Hanslip, J.; Yoshida, N.; Morilla, R. A classification of acute leukaemia for the 1990s. Ann. Hematol. 1991, 62, 16-21. [CrossRef]

10. Bene, M.C.; Castoldi, G.; Knapp, W.; Ludwig, W.D.; Matutes, E.; Orfao, A.; Van't Veer, M.B. Proposals for the immunological classification of acute leukemias. European Group for the Immunological Characterization of Leukemias (EGIL). Leukemia 1995, 9 , 1783-1786.

11. Wolach, O.; Stone, R.M. How I treat mixed-phenotype acute leukemia. Blood 2015, 125, 2477-2485. [CrossRef] 
12. Alexander, T.B.; Gu, Z.; Iacobucci, I.; Dickerson, K.; Choi, J.K.; Xu, B.; Payne-Turner, D.; Yoshihara, H.; Loh, M.L.; Horan, J.; et al. The genetic basis and cell of origin of mixed phenotype acute leukaemia. Nature 2018, 562, 373-379. [CrossRef]

13. Kotrova, M.; Musilova, A.; Stuchly, J.; Fiser, K.; Starkova, J.; Mejstrikova, E.; Stary, J.; Zuna, J.; Hrusak, O.; Trka, J.; et al. Distinct bilineal leukemia immunophenotypes are not genetically determined. Blood 2016, 128, 2263-2266. [CrossRef]

14. Manola, K.N.; Panitsas, F.; Polychronopoulou, S.; Daraki, A.; Karakosta, M.; Stavropoulou, C.; Avgerinou, G.; Hatzipantelis, E.; Pantelias, G.; Sambani, C.; et al. Cytogenetic abnormalities and monosomal karyotypes in children and adolescents with acute myeloid leukemia: Correlations with clinical characteristics and outcome. Cancer Genet. 2013, 206, 63-72. [CrossRef]

15. Rubnitz, J.E.; Onciu, M.; Pounds, S.; Shurtleff, S.; Cao, X.; Raimondi, S.C.; Behm, F.G.; Campana, D.; Razzouk, B.; Ribeiro, R.C.; et al. Acute mixed lineage leukemia in children: The experience of St Jude Children's Research Hospital. Blood 2009, 113, 5083-5089. [CrossRef] [PubMed]

16. Al-Seraihy, A.S.; Owaidah, T.M.; Ayas, M.; El-Solh, H.; Al-Mahr, M.; Al-Ahmari, A.; Belgaumi, A.F. Clinical characteristics and outcome of children with biphenotypic acute leukemia. Haematologica 2009, 94, 1682-1690. [CrossRef]

17. Park, J.A.; Ghim, T.T.; Bae, K.W.; Im, H.J.; Jang, S.S.; Park, C.J.; Chi, H.S.; Seo, J.J. Stem cell transplant in the treatment of childhood biphenotypic acute leukemia. Pediatr. Blood Cancer 2009, 53, 444-452. [CrossRef] [PubMed]

18. Xiao, W.; Bharadwaj, M.; Levine, M.; Farnhoud, N.; Pastore, F.; Getta, B.M.; Hultquist, A.; Famulare, C.; Medina-Martínez, J.S.; Patel, M.A.; et al. PHF6 and DNMT3A mutations are enriched in distinct subgroups of mixed phenotype acute leukemia with T-lineage differentiation. Blood Adv. 2018, 2, 3526-3539. [CrossRef] [PubMed]

19. Takahashi, K.; Wang, F.; Morita, K.; Yan, Y.; Hu, P.; Zhao, P.; Zhar, A.A.; Wu, C.J.; Gumbs, C.; Little, L.; et al. Integrative genomic analysis of adult mixed phenotype acute leukemia delineates lineage associated molecular subtypes. Nat. Commun. 2018, 9, 1-12. [CrossRef]

20. Hu, T.; Murdaugh, R.; Nakada, D. Transcriptional and Microenvironmental Regulation of Lineage Ambiguity in Leukemia. Front. Oncol. 2017, 7, 268. [CrossRef] [PubMed]

21. Rayes, A.; McMasters, R.L.; O'Brien, M.M. Lineage Switch in MLL-Rearranged Infant Leukemia Following CD19-Directed Therapy. Pediatr. Blood Cancer 2016, 63, 1113-1115. [CrossRef]

22. Fujisaki, H.; Hara, J.; Takai, K.; Nakanishi, K.; Matsuda, Y.; Ohta, H.; Osugi, Y.; Tokimasa, S.; Taniike, M.; Hosoi, G.; et al. Lineage switch in childhood leukemia with monosomy 7 and reverse of lineage switch in severe combined immunodeficient mice. Exp. Hematol. 1999, 27, 826-833. [CrossRef]

23. Burda, P.; Laslo, P.; Stopka, T. The role of PU.1 and GATA-1 transcription factors during normal and leukemogenic hematopoiesis. Leukemia 2010, 24, 1249-1257. [CrossRef] [PubMed]

24. Monma, F.; Nishii, K.; Ezuki, S.; Miyazaki, T.; Yamamori, S.; Usui, E.; Sugimoto, Y.; Lorenzo, V.F.; Katayama, N.; Shiku, H. Molecular and phenotypic analysis of Philadelphia chromosome-positive bilineage leukemia: Possibility of a lineage switch from T-lymphoid leukemic progenitor to myeloid cells. Cancer Genet. Cytogenet. 2006, 164, 118-121. [CrossRef]

25. Yeh, J.-R.J.; Munson, K.M.; Chao, Y.L.; Peterson, Q.P.; MacRae, C.A.; Peterson, R.T. AML1-ETO reprograms hematopoietic cell fate by downregulating scl expression. Development 2008, 135, 401-410. [CrossRef] [PubMed]

26. Jacoby, E.; Nguyen, S.M.; Fountaine, T.J.; Welp, K.; Gryder, B.; Qin, H.; Yang, Y.; Chien, C.D.; Seif, A.; Lei, H.; et al. CD19 CAR immune pressure induces B-precursor acute lymphoblastic leukaemia lineage switch exposing inherent leukaemic plasticity. Nat. Commun. 2016, 7, 12320. [CrossRef] [PubMed]

27. McClellan, J.S.; Dove, C.; Gentles, A.J.; Ryan, C.; Majeti, R. Reprogramming of primary human Philadelphia chromosome-positive B cell acute lymphoblastic leukemia cells into nonleukemic macrophages. Proc. Natl. Acad. Sci. USA 2015, 112, 4074-4079. [CrossRef]

28. Janz, M.; Dörken, B.; Mathas, S. Reprogramming of B Lymphoid Cells in Human Lymphoma Pathogenesis. Cell Cycle 2006, 5, 1057-1061. [CrossRef] [PubMed]

29. Shain, K.H.; Dalton, W.S.; Tao, J. The tumor microenvironment shapes hallmarks of mature B-cell malignancies. Oncogene 2015, 34, 4673-4682. [CrossRef]

30. Balducci, E.; Nivaggioni, V.; Boudjarane, J.; Bouriche, L.; Rahal, I.; Bernot, D.; Alazard, E.; Duployez, N.; Grardel, N.; Arnoux, I.; et al. Lineage switch from B acute lymphoblastic leukemia to acute monocytic leukemia with persistent $t(4 ; 11)(q 21 ; q 23)$ and cytogenetic evolution under CD19-targeted therapy. Ann. Hematol. 2017, 96, 1579-1581. [CrossRef]

31. Gardner, R.; Wu, D.; Cherian, S.; Fang, M.; Hanafi, L.-A.; Finney, O.; Smithers, H.; Jensen, M.C.; Riddell, S.R.; Maloney, D.G.; et al. Acquisition of a CD19-negative myeloid phenotype allows immune escape of MLL-rearranged B-ALL from CD19 CAR-T-cell therapy. Blood 2016, 127, 2406-2410. [CrossRef]

32. Berry, D.A.; Zhou, S.; Higley, H.; Mukundan, L.; Fu, S.; Reaman, G.H.; Wood, B.L.; Kelloff, G.J.; Jessup, J.M.; Radich, J.P. Association of Minimal Residual Disease With Clinical Outcome in Pediatric and Adult Acute Lymphoblastic Leukemia: A Meta-analysis. JAMA Oncol. 2017, 3, e170580. [CrossRef]

33. Mejstrikova, E.; Volejnikova, J.; Fronkova, E.; Zdrahalova, K.; Kalina, T.; Sterba, J.; Jabali, Y.; Mihal, V.; Blazek, B.; Cerna, Z.; et al. Prognosis of children with mixed phenotype acute leukemia treated on the basis of consistent immunophenotypic criteria. Haematologica 2010, 95, 928-935. [CrossRef]

34. Béné, M.C. Biphenotypic, bilineal, ambiguous or mixed lineage: Strange leukemias! Haematologica 2009, 94, 891-893. [CrossRef] 
35. Rasekh, E.O.; Osman, R.; Ibraheem, D.; Madney, Y.; Radwan, E.; Gameel, A.; Abdelhafiz, A.; Kamel, A.; Elfishawi, S. Acute lymphoblastic leukemia-like treatment regimen provides better response in mixed phenotype acute leukemia: A comparative study between adults and pediatric MPAL patients. Ann. Hematol. 2021, 100, 699-707. [CrossRef]

36. Hrusak, O.; De Haas, V.; Stancikova, J.; Vakrmanova, B.; Janotova, I.; Mejstrikova, E.; Capek, V.; Trka, J.; Zaliova, M.; Luks, A.; et al. International cooperative study identifies treatment strategy in childhood ambiguous lineage leukemia. Blood 2018, 132, 264-276. [CrossRef]

37. Brethon, B.; Lainey, E.; Caye-Eude, A.; Grain, A.; Fenneteau, O.; Yakouben, K.; Roupret-Serzec, J.; Le Mouel, L.; Cavé, H.; Baruchel, A. Case Report: Targeting 2 Antigens as a Promising Strategy in Mixed Phenotype Acute Leukemia: Combination of Blinatumomab With Gemtuzumab Ozogamicin in an Infant With a KMT2A-Rearranged Leukemia. Front. Oncol. 2021, $11,637951$. [CrossRef] [PubMed]

38. Shi, R.; Munker, R. Survival of patients with mixed phenotype acute leukemias: A large population-based study. Leuk. Res. 2015, 39, 606-616. [CrossRef] [PubMed]

39. Seetharam, S.; Thankamony, P.; Gopakumar, K.G.; Nair, R.A.; Jacob, P.M.; Krishna, K.M.J.; Rajeswari, B.; Nair, M.; Guruprasad, C.S.; Prasanth, V.R. Outcomes of pediatric mixed phenotype acute leukemia treated with lymphoid directed therapy: Analysis of an institutional series from India. Pediatr. Hematol. Oncol. 2021, 38, 358-366. [CrossRef]

40. Oberley, M.J.; Raikar, S.; Wertheim, G.B.; Malvar, J.; Sposto, R.; Rabin, K.R.; Punia, J.N.; Seif, A.E.; Cahen, V.C.; Schore, R.J.; et al. Significance of minimal residual disease in pediatric mixed phenotype acute leukemia: A multicenter cohort study. Leuk. 2020, 34, 1741-1750. [CrossRef] [PubMed]

41. Duong, V.H.; Begna, K.H.; Kashanian, S.; Sweet, K.; Wang, E.S.; Caddell, R.; Shafer, D.A.; Singh, Z.N.; Baer, M.R.; Al-Kali, A. Favorable outcomes of acute leukemias of ambiguous lineage treated with hyperCVAD: A multi-center retrospective study. Ann. Hematol. 2020, 99, 2119-2124. [CrossRef]

42. Bachir, F.; Zerrouk, J.; Howard, S.C.; Graoui, O.; Lahjouji, A.; Hessissen, L.; Bennani, S.; Quessar, A.; El Aouad, R. Outcomes in Patients With Mixed Phenotype Acute Leukemia in Morocco. J. Pediatr. Hematol. 2014, 36, e392-e397. [CrossRef]

43. Gerr, H.; Zimmermann, M.; Schrappe, M.; Dworzak, M.; Ludwig, W.-D.; Bradtke, J.; Moericke, A.; Schabath, R.; Creutzig, U.; Reinhardt, D. Acute leukaemias of ambiguous lineage in children: Characterization, prognosis and therapy recommendations. Br. J. Haematol. 2010, 149, 84-92. [CrossRef] [PubMed]

44. Reid, J.H.; Perissinotti, A.J.; Benitez, L.L.; Boyer, D.; Lee, W.; Burke, P.W.; Pettit, K.; Bixby, D.L.; Marini, B.L. Hybrid chemotherapy regimen (FLAG-IDA-vincristine-prednisone) for acute leukemia with mixed-phenotype blasts. Leuk. Res. 2021, 103, 106539. [CrossRef] [PubMed]

45. Lazarus, H.M.; Richards, S.M.; Chopra, R.; Litzow, M.R.; Burnett, A.K.; Wiernik, P.H.; Franklin, I.M.; Tallman, M.S.; Cook, L.; Buck, G.; et al. Central nervous system involvement in adult acute lymphoblastic leukemia at diagnosis: Results from the international ALL trial MRC UKALL XII/ECOG E2993. Blood 2006, 108, 465-472. [CrossRef] [PubMed]

46. Raikar, S.S.; Park, S.I.; Leong, T.; Jaye, D.L.; Keller, F.G.; Horan, J.T.; Woods, W.G. Isolated myeloperoxidase expression in pediatric B/myeloid mixed phenotype acute leukemia is linked with better survival. Blood 2018, 131, 573-577. [CrossRef]

47. Winters, A.C.; Bernt, K.M. MLL-Rearranged Leukemias-An Update on Science and Clinical Approaches. Front. Pediatr. 2017, 5, 4. [CrossRef] [PubMed]

48. Young, K.; Loberg, M.A.; Eudy, E.; Schwartz, L.S.; Mujica, K.D.; Trowbridge, J.J. Heritable genetic background alters survival and phenotype of Mll-AF9-induced leukemias. Exp. Hematol. 2020, 89, 61-67.e3. [CrossRef]

49. Qasrawi, A.; Ramlal, R.; Munker, R.; Hildebrandt, G.C. Prognostic impact of Philadelphia chromosome in mixed phenotype acute leukemia (MPAL): A cancer registry analysis on real-world outcome. Am. J. Hematol. 2020, 95, 1015-1021. [CrossRef] [PubMed]

50. Shimizu, H.; Saitoh, T.; Machida, S.; Kako, S.; Doki, N.; Mori, T.; Sakura, T.; Kanda, Y.; Kanamori, H.; Miyawaki, S.; et al Allogeneic hematopoietic stem cell transplantation for adult patients with mixed phenotype acute leukemia: Results of a matched-pair analysis. Eur. J. Haematol. 2015, 95, 455-460. [CrossRef]

51. Tian, H.; Xu, Y.; Liu, L.; Yan, L.; Jin, Z.; Tang, X.; Han, Y.; Fu, Z.; Qiu, H.; Sun, A.; et al. Comparison of outcomes in mixed phenotype acute leukemia patients treated with chemotherapy and stem cell transplantation versus chemotherapy alone. Leuk. Res. 2016, 45, 40-46. [CrossRef]

52. Issa, G.C.; Ravandi, F.; DiNardo, C.D.; Jabbour, E.; Kantarjian, H.M.; Andreeff, M. Therapeutic implications of menin inhibition in acute leukemias. Leukemia 2021, 35, 2482-2495. [CrossRef] [PubMed]

53. Stein, E.M.; Garcia-Manero, G.; Rizzieri, D.A.; Tibes, R.; Berdeja, J.G.; Savona, M.R.; Jongen-Lavrenic, M.; Altman, J.K.; Thomson, B.; Blakemore, S.J.; et al. The DOT1L inhibitor pinometostat reduces H3K79 methylation and has modest clinical activity in adult acute leukemia. Blood 2018, 131, 2661-2669. [CrossRef] [PubMed]

54. Loftus, J.P.; Yahiaoui, A.; Brown, P.A.; Niswander, L.; Bagashev, A.; Wang, M.; Schauf, A.; Tannheimer, S.; Tasian, S.K. Combinatorial efficacy of entospletinib and chemotherapy in patient-derived xenograft models of infant acute lymphoblastic leukemia. Haematologica 2020, 106, 1067-1078. [CrossRef]

55. Milojkovic, D.; Ibrahim, A.; Reid, A.; Foroni, L.; Apperley, J.; Marin, D. Efficacy of combining dasatinib and FLAG-IDA for patients with chronic myeloid leukemia in blastic transformation. Haematologica 2011, 97, 473-474. [CrossRef] [PubMed]

56. Labrador, J.; Hermida, G.J.; Alvarez, R.; Anso, V.; De Vicente, P.; Goñi, M.; Gonzalez-Lopez, T.J. Dasatinib and FLAG-IDA Is an Effective Therapy for Initial Myeloid Blast Crisis but Involves a High Risk of Opportunistic Infections. Case Rep. Hematol. 2020, 2020, 1-4. [CrossRef] [PubMed] 
57. Munker, R.; Brazauskas, R.; Wang, H.L.; de Lima, M.; Khoury, H.J.; Gale, R.P.; Maziarz, R.T.; Sandmaier, B.M.; Weisdorf, D.; Saber, W. Allogeneic Hematopoietic Cell Transplantation for Patients with Mixed Phenotype Acute Leukemia. Biol. Blood Marrow Transplant. 2016, 22, 1024-1029. [CrossRef]

58. Getta, B.M.; Roshal, M.; Zheng, J.; Park, J.H.; Stein, E.M.; Levine, R.; Papadopoulos, E.B.; Jakubowski, A.A.; Kernan, N.A.; Steinherz, P.; et al. Allogeneic Hematopoietic Stem Cell Transplantation with Myeloablative Conditioning Is Associated with Favorable Outcomes in Mixed Phenotype Acute Leukemia. Biol. Blood Marrow Transplant. 2017, 23, 1879-1886. [CrossRef] [PubMed]

59. Munker, R.; Labopin, M.; Esteve, J.; Schmid, C.; Mohty, M.; Nagler, A. Mixed phenotype acute leukemia: Outcomes with allogeneic stem cell transplantation. A retrospective study from the Acute Leukemia Working Party of the EBMT. Haematologica 2017, 102, 2134-2140. [CrossRef] [PubMed]

60. Zając-Spychała, O.; Irga-Jaworska, N.; Drożyńska, E.; Muszyńska-Rosłan, K.; Krawczuk-Rybak, M.; Zawitkowska, J.; Kowalczyk, J.; Ćwiklińska, M.; Balwierz, W.; Mizia-Malarz, A.; et al. Mixed phenotype acute leukemia: Biological profile, clinical characteristic and treatment outcomes: Report of the population-based study. Eur. J. Haematol. 2020, 105, 85-93. [CrossRef]

61. Wood, B.L. Principles of minimal residual disease detection for hematopoietic neoplasms by flow cytometry. Cytom. Part B Clin. Cytom. 2016, 90, 47-53. [CrossRef]

62. Borowitz, M.J.; Wood, B.L.; Devidas, M.; Loh, M.L.; Raetz, E.A.; Salzer, W.L.; Nachman, J.B.; Carroll, A.J.; Heerema, N.A.; Gastier-Foster, J.M.; et al. Prognostic significance of minimal residual disease in high risk B-ALL: A report from Children's Oncology Group study AALL0232. Blood 2015, 126, 964-971. [CrossRef] [PubMed]

63. Choi, S.M.; Frederiksen, J.K.; Ross, C.W.; Bixby, D.L.; Shao, L. Philadelphia Chromosome-like Mixed-Phenotype Acute Leukemia Demonstrating P2RY8-CRLF2 Fusion and JAK1 Mutation. Am. J. Clin. Pathol. 2017, 148, 523-528. [CrossRef] [PubMed]

64. Roberts, K.G.; Li, Y.; Payne-Turner, D.; Harvey, R.C.; Yang, Y.-L.; Pei, D.; McCastlain, K.; Ding, L.; Lu, C.; Song, G.; et al. Targetable Kinase-Activating Lesions in Ph-like Acute Lymphoblastic Leukemia. N. Engl. J. Med. 2014, 371, 1005-1015. [CrossRef]

65. Shimizu, H.; Yokohama, A.; Hatsumi, N.; Takada, S.; Handa, H.; Sakura, T.; Nojima, Y. Philadelphia chromosome-positive mixed phenotype acute leukemia in the imatinib era. Eur. J. Haematol. 2014, 93, 297-301. [CrossRef] [PubMed]

66. Hoehn, D.; Medeiros, L.J.; Chen, S.S.; Tian, M.T.; Jorgensen, J.L.; Ahmed, Y.; Lin, P. CD117 Expression Is a Sensitive but Nonspecific Predictor ofFLT3Mutation in T Acute Lymphoblastic Leukemia and T/Myeloid Acute Leukemia. Am. J. Clin. Pathol. 2012, 137, 213-219. [CrossRef]

67. Manara, E.; Baron, E.; Tregnago, C.; Aveic, S.; Bisio, V.; Bresolin, S.; Masetti, R.; Locatelli, F.; Basso, G.; Pigazzi, M. MLL-AF6 fusion oncogene sequesters AF6 into the nucleus to trigger RAS activation in myeloid leukemia. Blood 2014, 124, 263-272. [CrossRef]

68. Mansur, M.B.; Ford, A.M.; Emerenciano, M. The role of RAS mutations in MLL -rearranged leukaemia: A path to intervention? Biochim. Biophys. Acta (BBA) Bioenerg. 2017, 1868, 521-526. [CrossRef]

69. Stam, R. (Ronald) Targeting FLT3 in primary MLL-gene-rearranged infant acute lymphoblastic leukemia. Blood 2005, 106, 2484-2490. [CrossRef] [PubMed]

70. Wu, D.; Chen, W.; Chen, Z.; Li, Q. Venetoclax Combined with Hypomethylating Agents for Treatment-Naive B/Myeloid Mixed Phenotype Acute Leukemia. Case Rep. Hematol. 2021, 2021, 6661109. [CrossRef]

71. Bacchiarri, F.; Sammartano, V.; Santoni, A.; Raspadori, D.; Zappone, E.; Defina, M.; Ciofini, S.; Sicuranza, A.; Bocchia, M.; Gozzetti, A. First reported case of secondary mixed phenotype acute leukemia after multiple myeloma. Am. J. Blood Res. 2021, 11, 123-131. [PubMed]

72. Klocke, H.; Dong, Z.M.; O’Brien, C.; Burwick, N.; Richard, R.E.; Wu, D.Y.; Chauncey, T.R.; Graf, S.A. Venetoclax and Decitabine for T/Myeloid Mixed-Phenotype Acute Leukemia Not Otherwise Specified (MPAL NOS). Case Rep. Hematol. 2020, $2020,8811673$. [CrossRef]

73. Baeuerle, P.A.; Reinhardt, C. Bispecific T-Cell Engaging Antibodies for Cancer Therapy. Cancer Res. 2009, 69, 4941-4944. [CrossRef] [PubMed]

74. Goebeler, M.-E.; Bargou, R.C. T cell-engaging therapies-BiTEs and beyond. Nat. Rev. Clin. Oncol. 2020, 17, 418-434. [CrossRef]

75. Maude, S.L.; Teachey, D.; Porter, D.L.; Grupp, S.A. CD19-targeted chimeric antigen receptor T-cell therapy for acute lymphoblastic leukemia. Blood 2015, 125, 4017-4023. [CrossRef]

76. Park, J.H.; Geyer, M.B.; Brentjens, R.J. CD19-targeted CAR T-cell therapeutics for hematologic malignancies: Interpreting clinical outcomes to date. Blood 2016, 127, 3312-3320. [CrossRef]

77. Durer, S.; Shafqat, M.; Comba, I.Y.; Malik, S.; Faridi, W.; Aslam, S.; Ijaz, A.; Tariq, M.J.; Fraz, M.A.; Usman, M.; et al. Concomitant use of blinatumomab and donor lymphocyte infusion for mixed-phenotype acute leukemia: A case report with literature review. Immunotherapy 2019, 11, 373-378. [CrossRef]

78. El Chaer, F.; Ali, O.M.; Sausville, E.A.; Law, J.Y.; Lee, S.T.; Duong, V.H.; Baer, M.R.; Koka, R.; Singh, Z.N.; Wong, J.; et al. Treatment of CD19-positive mixed phenotype acute leukemia with blinatumomab. Am. J. Hematol. 2019, 94, E7-E8. [CrossRef]

79. Kong, D.; Qu, C.; Dai, H.; Li, Z.; Yin, J.; Chen, S.; Kang, L.; Chen, G.; Zhu, M.; Yu, L.; et al. CAR-T therapy bridging to allogeneic HSCT provides durable molecular remission of $\mathrm{Ph}+$ mixed phenotype acute leukaemia with minimal residual disease. $\mathrm{Br}$. $\mathrm{J}$. Haematol. 2020, 191, e47-e49. [CrossRef] [PubMed]

80. Li, M.-Y.; Lin, Z.-H.; Hu, M.-M.; Kang, L.-Q.; Wu, X.-X.; Chen, Q.-W.; Kong, X.; Zhang, J.; Qiu, H.-Y.; Wu, D.-P. Secondary donor-derived humanized CD19-modified CAR-T cells induce remission in relapsed/refractory mixed phenotype acute leukemia after allogeneic hematopoietic stem cell transplantation: A case report. Biomark. Res. 2020, 8, 1-6. [CrossRef] 
81. Bartram, J.; Balasch-Carulla, M.; Bhojaraja, S.; Adams, S.; Cheng, D.; Inglott, S.; Kulkarni, N.; Mahendrayogam, A.; O'Connor, O.; Pavasovic, V.; et al. Blinatumomab for paediatric mixed phenotype acute leukaemia. Br. J. Haematol. 2021. [CrossRef] [PubMed]

82. Roskopf, C.C.; Braciak, T.A.; Fenn, N.C.; Kobold, S.; Fey, G.H.; Hopfner, K.-P.; Oduncu, F.S. Dual-targeting triplebody 33-3-19 mediates selective lysis of biphenotypic CD19+ CD33+ leukemia cells. Oncotarget 2016, 7, 22579-22589. [CrossRef] [PubMed]

83. Hoseini, S.S.; Espinosa-Cotton, M.; Guo, H.-F.; Cheung, N.-K.V. Overcoming leukemia heterogeneity by combining T cell engaging bispecific antibodies. J. Immunother. Cancer 2020, 8, e001626. [CrossRef] [PubMed] 